\title{
Health Risk of Using Global System for Mobile Communication (GSM) Mobile Phone
}

\author{
Shalangwa, D. A., , Vasira, P. G., Waba, A. S \\ Department of Physics, Adamawa State University, Mubi
}

\begin{abstract}
Despite the fact that introduction of GSM technology and mobile phone had tremendously solved the problems of communication in Nigeria; however the health implication of radiation from GSM mobile phone has become an area of great concern to the public. This study tried to find out the effect of radiation emitted from GSM mobile phone on human health. Power density was measured from selected mobile phone of different model at $0.01 \mathrm{~m}$ away from the head of the mobile phone where large quantity of the radiation is emitted. The amount of power density measured ranges from 0.3 to $0.5 \mu \mathrm{W} / \mathrm{m}^{2}$ with the corresponding SAR ranges from 0.0011 to $0.0018 \mathrm{~W} / \mathrm{Kg}$. These results were compared with the standard values from the safety guide lines provided by the ICNIRP and were found to be far below the recommended level.
\end{abstract}

Keywords Human Health, Effect, Long Term, Exposure and Damage

\section{Introduction}

There are two groups that have controversies over safety level of using mobile phone in Adamawa State Nigeria, some group opine that radiation from mobile phone has effect on human health while other group opines that there is no any scientific evidence to prove that radiation from mobile phone has effect on human health, this work intended to find out the relationship between human health and radio frequency (RF) radiated from Global system for mobile communication (GSM) phone since people use it in their everyday life as the easies means of communication. Many researched have been carried out to find out whether these two relations exist although the results of different finding contradicts each other, because of that people are not yet much more convinced. According to some researchers, long term exposure of RF for at least 10 years could have effect on human health, see[5]. Some researcher also highlighted on effect of radiation emitted from mobile phone on specific organ in human body like Brain, eye and testes; radiation from $1800 \mathrm{MHz}$ mobile phone could cause damage to some part of brain[1\&4], RF exposure on eyes, ear and testes, are particularly vulnerable to RF heating because of the insufficient blood flow to dissipate heat load[2 \& 7]. Some research in other areas also stated that there is risk of RF radiation to pregnant women[ $6,8 \& 9]$. This work tried to measure power density from selected GSM phone and

* Corresponding author:

deshalangs3g@yahoo.com (Shalangwa, D. A.)

Published online at http://journal.sapub.org/ijea

Copyright (C) 2011 Scientific \& Academic Publishing. All Rights Reserved calculates the specific absorption rate (SAR) with the aim of getting results that may satisfy the interest of people using GSM phones in Adamawa State Nigeria.

Although some group like the International Commission on non ionizing radiation protection (ICNIRP) and mobile manufacturer forum (MMF) that manufactures mobile equipments and GSM operators across the world insists that there are no discernible effects from the RF radiated from base station and mobile phone. Therefore, to confirm these positions whether there is scientific evidence or not to suggest that the low power emission levels are inimical to human or animal health; this now prompted the demand for this work.

\section{Material and Method}

The materials used are electromagnetic detection device and some selected handsets; like Nokia model, Motorola, sagem, Zain, Sony Ericson, Nec, Novo, I - Tel and G - Tide. The method is classified into two that is method of data collection and method of data analysis.

\subsection{Method of Data Collection}

The measuring instrument was place $0.01 \mathrm{~m}$ from the head of GSM handset for 1 minute then the power density in $\left(\mu \mathrm{W} / \mathrm{m}^{2}\right)$ was monitored and recorded.

\subsection{Method of Data Analysis}

Haven measured the power density; the power density measured is express mathematically as

$$
P_{D}=\frac{E^{2}}{Z_{0}}
$$


Where $E$ is the electric field, $Z_{0}$ is the free space impedence equivalent to $120 \pi$ or $3777 \Omega$. The electric field assumed all the components of the electric field in $\mathrm{x}, \mathrm{y}, \mathrm{z}$ plane which may be further express as

$$
E^{2}=E_{x}^{2}+E_{y}^{2}+E_{z}^{2}
$$

To determine the SAR we have to know the values of the electric field, from equation (1), we have

$$
E^{2}=3777 P_{D}
$$

Then the SAR is usually define in terms of electric field or in respect to change in temperature given by

$$
S A R=\sigma \frac{E^{2}}{\rho}=c \frac{d T}{d t} \mid t \rightarrow 0
$$

Neglecting the temperature effects and the specific heat capacity (c), then the required SAR becomes[10]

$$
S A R=\sigma \frac{E^{2}}{\rho}
$$

Where $\sigma$ is the conductivity measured in $(\Omega-1 \mathrm{~m}-1)$ and $\rho$ is the mass density in (Kgm-3), substituting equation (3) into (4) it yield

$$
S A R=\frac{3777 \sigma P_{D}}{\rho}
$$

Equation (6) defines average the SAR of the whole body and SAR of localized part of the body (head).

While Table 1 and 2 give the summary of the Human brain tissue dielectric parameter and the ICNIPR's general public safety guide lines for limiting radiation exposure and SAR.

Table 1. Summary of the Human brain tissue dielectric parameter[10]

\begin{tabular}{ccc}
\hline $\mathrm{F}(\mathrm{MHz})$ & $\sigma(\Omega-1 \mathrm{~m}-1)$ & $\rho(\mathrm{Kgm}-1)$ \\
\hline 900 & 0.7665 & 1030 \\
1800 & 1.1531 & 1030 \\
\hline
\end{tabular}

Table 2. Summary of the ICNIPR's general public safety guide lines for limiting radiation exposure and SAR.[10]

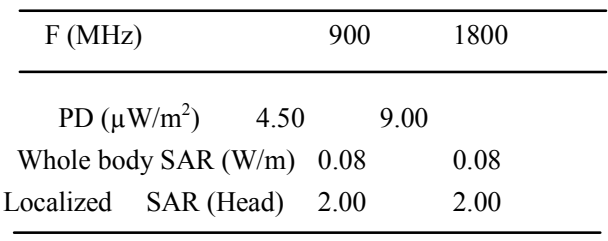

\section{Results}

All the power densities measured from each GSM mobile phones are presented in Table $3-7$ as follows:

Table 3. Radiation from Nokia mobile phone with MTN SIM Card

\begin{tabular}{ccc}
\hline $\begin{array}{c}\text { Mobile Phone } \\
\text { Type }\end{array}$ & Power Density & SAR \\
\hline (Model) & $\left(\mu \mathrm{W} / \mathrm{m}^{2}\right)$ & $\left(\mathrm{Kg} / \mathrm{m}^{2}\right)$ \\
\hline Nokia 616 & 0.350 & 0.0012 \\
Nokia 1100 & 0.400 & 0.0015 \\
Nokia 1200 & 0.300 & 0.0011 \\
Nokia 3310 & 0.300 & 0.0011 \\
Nokia 3330 & 0.300 & 0.0011 \\
\hline
\end{tabular}

Table 4. Radiation from Motorola mobile phone with MTN SIM Card

\begin{tabular}{lcc}
\hline $\begin{array}{l}\text { Mobile Phone Type } \\
\text { (Model) }\end{array}$ & $\begin{array}{c}\text { Power Density } \\
(\mu \mathrm{W} / \mathrm{m} 2)\end{array}$ & $\begin{array}{c}\text { SAR } \\
\left(\mathrm{Kg} / \mathrm{m}^{2}\right)\end{array}$ \\
\hline Motorola L 6 & 0.500 & 0.0018 \\
Motorola L 7 & 0.400 & 0.0015 \\
Motorola L 9 & 0.400 & 0.0015 \\
Motorola C 117 & 0.450 & 0.0017 \\
Motorola C 117 & 0.450 & 0.0017 \\
\hline
\end{tabular}

Table 5. Radiation from Sagem mobile phone with MTN SIM Card

\begin{tabular}{lcc}
\hline $\begin{array}{l}\text { Mobile Phone Type } \\
\text { (Model) }\end{array}$ & $\begin{array}{c}\text { Power Density } \\
\left(\mu \mathrm{W} / \mathrm{m}^{2}\right)\end{array}$ & $\begin{array}{c}\mathrm{SAR} \\
\left(\mathrm{Kg} / \mathrm{m}^{2}\right)\end{array}$ \\
\hline Sagem C 17 & 0.400 & 0.0015 \\
Sagem C 19 & 0.400 & 0.0015 \\
Sagem MYX5 & 0.400 & 0.0015 \\
Sagem MYX7 & 0.500 & 0.0018 \\
Sagem BIRD & 0.300 & 0.0011 \\
\hline
\end{tabular}

Table 6. Radiation from Sony/Ericson/Zain mobile phone with MTN SIM Card

\begin{tabular}{ccc}
\hline $\begin{array}{c}\text { Mobile Phone Type } \\
\text { (Model) }\end{array}$ & $\begin{array}{c}\text { Power Density } \\
\left(\mu \mathrm{W} / \mathrm{m}^{2}\right)\end{array}$ & $\begin{array}{c}\text { SAR } \\
\left(\mathrm{Kg} / \mathrm{m}^{2}\right)\end{array}$ \\
\hline Sony Ericson & 0.400 & 0.0015 \\
Sony & 0.300 & 0.0011 \\
Zain 1 & 0.300 & 0.0011 \\
Zain 2 & 0.300 & 0.0011 \\
Zain 3 & 0.400 & 0.0015 \\
\hline
\end{tabular}

Table 7. Radiation from Nec and others mobile phone with MTN SIM Card

\begin{tabular}{ccc}
\hline $\begin{array}{c}\text { Mobile Phone Type } \\
\text { (Model) }\end{array}$ & $\begin{array}{c}\text { Power Density } \\
\left(\mu \mathrm{W} / \mathrm{m}^{2}\right)\end{array}$ & $\begin{array}{c}\text { SAR } \\
\left(\mathrm{Kg} / \mathrm{m}^{2}\right)\end{array}$ \\
\hline Nec 116 & 0.450 & 0.0017 \\
Nec 616 & 0.500 & 0.0018 \\
Novo & 0.450 & 0.0017 \\
I - Tel & 0.400 & 0.0015 \\
G - Tide 78 & 0.400 & 0.0015 \\
\hline
\end{tabular}

\section{Discussion}

The results obtained are shown in Table $3-7$, which present the power density measured from the selected handsets at $0.01 \mathrm{~m}$ from the head of the electromagnetic detector. The power density measured is expressed in micro watt per square meter $\left(\mu \mathrm{W} / \mathrm{m}^{2}\right)$ while the corresponding SAR were obtained from Equation (6) which is expressed in watt per kilogram $(\mathrm{W} / \mathrm{Kg})$. In order to define clearly the level of radiation emitted from the GSM mobile phones, a plot of power density measured from the mobile phone of different models are presented in columns as shown in Figure 1 and 2. The results obtained in this investigation indicate that GSM mobile phone radiates electromagnetic waves in the order of 0.3 to $0.5 \mu \mathrm{W} / \mathrm{m}^{2}$ for the selected mobile phone models place at $0.01 \mathrm{~m}$ from electromagnetic detector. Although there is variation in the power density detected from the different models of the mobile phone even does that are manufactured by the same company; this may be attributed to the design 
specification of each handset. Figure1 shows that radiation from Sagem MYX7, Nec 616 and Motorola L6 $\left(0.5 \mu \mathrm{W} / \mathrm{m}^{2}\right)$, appeared to be the highest while $\left(0.3 \mu \mathrm{W} / \mathrm{m}^{2}\right)$ were the least as shown in Figure 1, these results were then compared with the safety guidelines from the ICNRIP which range from 4.5 to $9.0 \mu \mathrm{W} / \mathrm{m}^{2}$, this far below the recommended level.

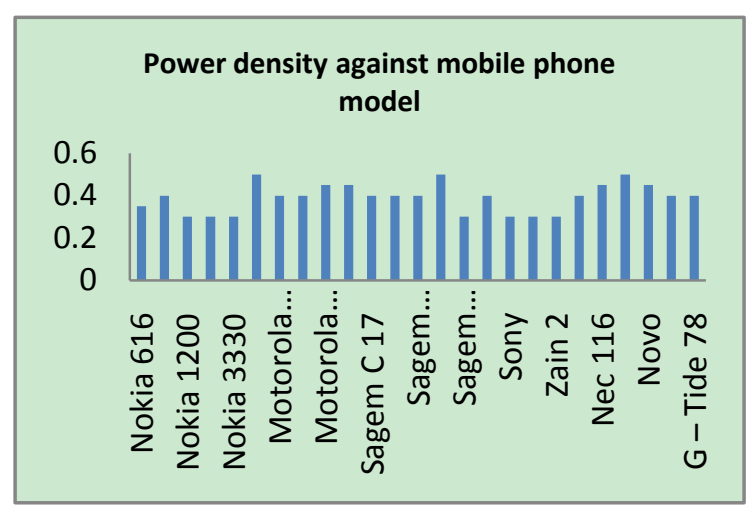

Figure 1. Power density against mobile phone model

The corresponding SAR values for Sagem MYX7, Nec 616 and Motorola L6 shown in Figure 2 seem to be highest $(0.0018 \mathrm{~W} / \mathrm{Kg})$ while that of Zain 1, 2, Sony, Nokia 1200 , 3310,3330 and Sagem Bird $(0.0011 \mathrm{~W} / \mathrm{Kg})$ were the least. These results were also compared with the results endorsed by the UK Government that was made by the[3] adopted by the European Union Council. These recommendations set a SAR limit of $2.0 \mathrm{~W} / \mathrm{kg}$ in $10 \mathrm{~g}$ of tissue, was also found to be far below safety guide lines.

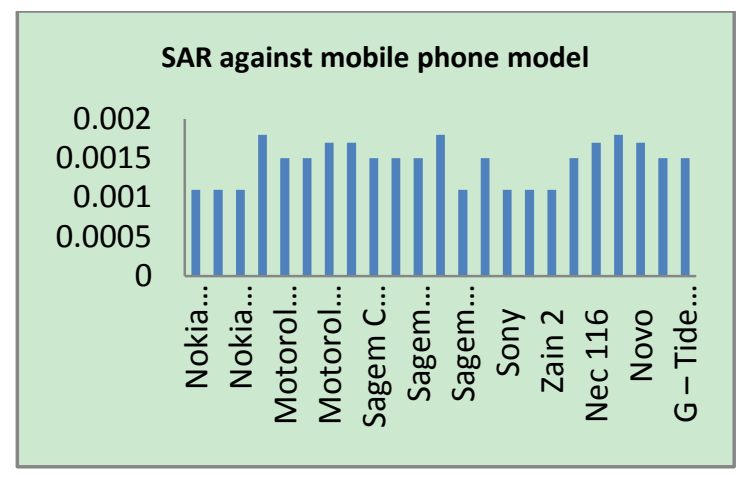

Figure 2. SAR against mobile phone model

\section{Conclusions}

The study was carried out successfully, maximum power density measured was found to range from 0.3 to $0.5 \mu \mathrm{W} / \mathrm{m}^{2}$ with the corresponding SAR ranged from 0.0011 to 0.0018 $\mathrm{W} / \mathrm{kg}$, these results were compared with the standard values provided by the ICNIPR and the study shows that the measured power density for the selected mobile phone was found to be far below safety margin. This work put more emphasis on the mathematical approach rather than the laboratory approach. We hope this study had provided some answers to the several questions posed by the Nigerian citizen on the health implication of using GSM mobile phone in Nigeria. Despite the fact that this study shows that it is safe to use mobile phone, as additional margin of safety. The following recommendation can be put in place to avoid excessive exposure,

1. When going to your bed switch off your mobile phone or keep it far away from you.

2. Avoid frequent contact/ call or used microphone instead of placing mobile phone close to your ear.

3. Pregnant should keep their mobile phone way from them.

4. Send your message through text instead of regular calls.

\section{REFERENCES}

[1] Dariusz, L., Sakari, J., Jukka, R. and Reetta, K. 2002. Non thermal activation of the hsp27/p38 MAPK stress pathway by mobile phone radiation in Human endothelial cells, molecular mechanism for cancer and blood barrier related effects, Blackwell verlay publishers 70:120 - 129 .

[2] Hyland G J. 2000. How exposure to GSM base station radiation can adversely affects human, Department of Physics International Institute of Biophysics university of Warwick Neuss - Helzheim Coventry.

[3] ICNIRP 2009. Summary of the ICNIPR's general public safety guide lines for limiting radiation exposure and SAR. Available on http//:www.ICNIRP.com

[4] Leif, S., Arne, E., Jacob, LE., Lars, M., Bertil, R. and Persson, R. 2003. Nerve cell damage in mammalian brain after exposure to microwave phone. Journal of Environmental health perspectives 111(7): $881-883$.

[5] Lennart, H., Michael, C., Fredrick, S., Kjell, HM. and Morgan, L. 2007. Long - term use of cellular mobile phone and brain tumor; increased risk associated with use greater or equal to 10 years. Journal of Occupational Environmental Med.

[6] Loque, JN., Hamburger, S., Silverman PM, Chiachierini RP 2004. Congenital anomalies and paternal occupational exposure to short wave, microwave, infrared and acoustic radiation. Journal of environmental health prospective 112(17): $1733-1801$

[7] Paolo, R. 2007. Potential adverse effect of GSM cellular phones on hearing. EU research on environmental and health - Results from project funded by fifth framework programmed: $168-169$.

[8] Persson, BRR. 1997. Blood brain barrier permeability in rats exposed to electromagnetic fields used in wireless communication and wireless network. Kluwer Academic Publishers 461 Hingham MA USA: 455.

[9] Thomas, H., Uwe, M., and Peter, S. 2002. Nonstop pulsed radiation inside home. 2nd International workshop on Biological effects of electromagnetic fields: $775-780$.

[10] Ismail, ANM., Din, MZJ anad Balasubramaniam, N. 2010. Mobile phone base station radiation study for addressing public concern. American Journal of Engineering and applied science 3(1): $117-120$ 